\title{
Political Culture and Nigeria's Democratic Experience in the Fourth Republic
}

\section{CHIGOZIE JOSEPH NEBEIFE ${ }^{*} \&$ MARKUS ARUM IZANG** \& AL CHUKWUMA OKOLI*1 $^{* * 1}$}

${ }^{*}$ Department of Political Science, Faculty of Humanities, Management and Social Sciences, Federal University Wukari, Nigeria

${ }^{* *}$ Department of Political Science, Faculty of Social Sciences, Federal University of Lafia, Nigeria

\begin{abstract}
Since Nigeria's return to civilian rule in 1999, the quest to sustain and mainstream democratic practice and governance has continued to play a vital role in the country's political life. While electoral democracy is universally acclaimed as the quintessence of good governance, Nigeria's democratic experience has been apparently contradictory. This paper explores some contemporary issues of democracy and governance in Nigeria from the standpoint of the country's prevailing undemocratic political culture. The descriptive qualitative analysis focuses on salient aspects of democratic culture. The paper posits that Nigerian's democratic prospects have been undermined by its persistent undemocratic political culture. With reference to the country's Fourth Republic, the paper highlights the critical implications of such an anomalous culture for Nigeria's democratic aspirations and governance experience, noting that radical civic re-orientation is a desideratum for any change to the status quo.
\end{abstract}

\section{Keywords}

Nigeria, democracy, democratic experience, elections, opportunism, political culture

DOI: https://doi.org/10.24132/cejop_2021_2

How to cite: Nebeife, C.J., Izang, M.A., and Okoli, A.C. 2021. "Political Culture and Nigeria's Democratic Experience in the Fourth Republic." Central European Journal of Politics 7 (1): 30-45. DOI: 10.24132/cejop_2021_2

\footnotetext{
1 Address: Chigozie Joseph Nebeife, Lecturer, Department of Political Science, Faculty of Humanities, Management and Social Sciences, Federal University Wukari, PMB 1021, Katsina-Ala Road, Wukari, Taraba State, Nigeria. E-mail: cjnebeife@gmail.com. Markus Aurum Izang, C/o Department of Political Science, Faculty of Social Sciences, Federal University of Lafia, PMB 146, Maraba Akunza, Obi Road, Lafia, Nasarawa State, Nigeria. E-mail: arummarkus@gmail.com. Al Chukwuma Okoli, PhD, Senior Lecturer, Department of Political Science, Faculty of Social Sciences, Federal University of Lafia, PMB 146, Maraba Akunza, Obi Road, Lafia, Nasarawa State, Nigeria. E-mail: okochu007@yahoo.com.
} 


\section{Introduction}

Democracy has become a global trend in line with the third wave of democratization (Huntington 1991; McFaul 2002; Doorenspleet 2005), which propelled authoritarian regimes in most countries to transform into some forms of civil rule. Since the latest return to democratic rule in Nigeria in 1999, the challenges of consolidating democracy have occupied a pivotal place. This year [1999] marked another era of democratic governance and the birth of the Fourth Republic in Nigeria. Since then, Nigeria has engaged in six general elections between 1999 and 2019. Although these elections have been able to sustain democracy, it has been associated with myriads of shortcomings occasioned by attitudes of the political actors.

The 2003, 2007, 2011 and 2015 general elections in Nigeria were fraught with irregularities of different sorts. While the 2007 elections were marred with irregularities, the 2011 election was dented with bloody post-election crisis, which led to over 800 deaths and 65,000 human displacement (Odigbo 2015). Nwanegbo and Alumona (2011) posit that the overarching influence of the incumbents on the electoral administration results to manipulation of the electoral process in Nigeria. Other analysts such as Jega and Ibeanu (2007), Jega (2007), Omotola (2014), as well as Okoli and Orinya (2013), have argued variously that political opportunism, oppositional intolerance, and poor dispensation of electoral administration have undermined credible elections in Nigeria.

However, when democracy is practiced without the right and enabling political culture, the sustenance and consolidation of the practice cannot be sustainably guaranteed. By democratic consolidation is meant strengthening, entrenching and institutionalizing the requisite norms, values, structures and institutions. In the view of Linz and Stepan (1996: 10), "democracy is consolidated when under given political and economic conditions, a democratic system expressed in periodic and regular elections becomes the only game in town; when no one can imagine acting outside the democratic norms and values." Sustaining democratic, however, requires a thriving conscious civic political culture that guarantees popular governance processes as well as leverages optimal safeguards against authoritarian relapse (Przeworski 1997; Zakaria 1997; Carothers 2007).

Given the significance of political culture as a veritable determinant of the state of the democratic practice as espoused by Jackman and Miller (1996), it could be contended that Nigeria's democratic experience seems to have been cursed by the arcane culture of political opportunism. Similarly, Okoli and Orinya (2013) observed that the prevalence of opportunistic political culture in Nigeria threatens the achievement of credible elections to the effect that electoral democracy in Nigeria has largely appeared to be a sham. Invariably, credible electoral process which is universally acclaimed as the quintessence of democracy seems to have been lacking with regard to Nigeria's Fourth Republic. This paper examines the linkage between political culture and the political processes in 
Nigeria's Fourth Republic, with an insight on how that matters for the country's democratic and governance experiences.

\section{Political culture versus political opportunism}

Political culture refers to the totality of citizens' orientations, ideas, values, traditions and attitudes in relation to political objects in a political system. It highlights the pattern of individual's attitudes and orientations towards his political world (Almond and Verba 1965). People's political culture determines their actions and reactions as players in a political system (Okeke 2015). Types of political culture include civic, subject and parochial cultures. Civic culture is characterized by participatory dynamism and activism. It has to do with a population that is abreast and conscious of its political world. Under subject political culture, the citizenry is inclined to limited participation; they are more or less passive players in the system. In a parochial culture, the populace is oriented towards their traditional and primordial authorities and symbols of identification (Almond and Verba 1965).

This paper is anchored in the political culture framework. The concept of political culture highlights the dynamics of behavior of people in politics. Political culture presupposes the set of attitudes, beliefs and sentiments, which give order and meaning to a political process by providing the rules that govern the behavioral pattern in a political system (Weils 1994). It encompasses both the political ideals and the operating norms of a polity which deals with commonly shared goals and accepted rules as well as patterns of orientation to political objects such as parties, government, the constitution expressed in beliefs, symbols and values (Silver and Dowley 2000). The political culture theory was popularized by Almond and Verba (1965). It was further advanced by other prominent scholars such as Silver and Dowley (2000), Weils (1994), or Dahl (1971), amongst others.

More specifically, Silver and Dowley (2000) interpret political culture as a subjective mass phenomenon that consists of orientations towards key objects of the political system and the individual's role in the political system. Also, Weils (1994) states that political culture entails that part of culture relevant to politics, including political symbols, values, beliefs, attitudes, opinions, expectations, goals, and so on.

The essential attributes of a democratic political culture consist of civic engagement, political equality, solidarity, trust and tolerance, as well as social structures of co-operation. The theory of political culture is anchored in the assumption that people's political consent constitutes the basic foundation of legitimate political power and approach to change of government. Every political society has symbolic practices which determine the existence of political parties competing for political power and the degree of openness of political competitions and recruitment depends on the value and orientation of the political system (see Almond and Verba 1965; Inglehart and Welzel 2005). 
Political culture theory can be used in explaining political happenings in any political system. Its value lies in the fact that it exposes the socio-cultural imperatives that underpin the practice of politics as well as the conduct of public life in any political system. The implication of this is that the nature and character of politics in a political system reflects the essentials of its people's dominant political culture (Ibeanu and Orji 2014). Essentially, political culture differs from society to society as it is not naturally inclined but defined by each society's peculiarities and transferred from generation to generation through imitation and the society's agents of socialization.

With reference to Nigeria's democracy in the Fourth Republic, the political culture of the dominant elite has borne out critical trappings of political opportunism (Okoli and Orinya 2013). Political opportunism refers to lawless politicking whereby political actors pay no regard to etiquette, due diligence and moral cum legal restraint in their political engagements (Okoli and Orinya 2013). The opportunistic tendencies inherent in the prevailing political culture has been essentialized by elites' excesses of the political elites, which have been, more or less, occasioned by a number of variables, some of which are highlighted forthwith (Mbah 2007; Okeke 2017).

(1) Socio-economic factors: It is evident that people's social status as well as level of economic possession determines the way and manner in which they participate in politics. There are indications that most of those who are socioeconomically advantaged perceive politics as a civic priority and thus participate actively. On the other hand, their disadvantaged counterparts in urban and rural areas tend to distant themselves from politics, often with the reasoning that politics is a game for the wealthy; hence their passive political attitude (Mbah 2007). Besides, the political participation of the poor is inclined to be less objective and rational than that of the wealthy; the former is often susceptible to material inducement in the contexts of "money politics" and vote buying.

(2) Levels of educational attainment: Equally important in determining the political culture of a people is their level of general educational attainment and political awareness or civic consciousness. In Nigeria today, those who are fairly educated and politically conscientized through agents of political socialization tend to participate actively in politics. Those on the other side of the divide who wield little or no political enlightenment and consciousness hardly often care less about the political happenings in the polity. When they do, the tendency to political irrationality and gullibility among them is sure to be high.

(3) Ethnic/religious differences: Primordial prejudices and differences among ethnic groups are a crucial factor determining political culture and political participation in Nigeria. In contemporary Nigeria, any serious political undertaking has to first of all reckon with ethnic considerations. In other words, apart from the ethnicity plaguing Nigerian politics by dichotomizing its players at all levels, identity politics based on ethno-communal affinities constitutes a 
veritable denominator in party politics in Nigeria. In addition to ethnic cleavages, religion equally plays a key role in determining the complexion of political involvement in Nigeria's democracy. People now vote along their religious lines and fault-lines in national and local elections.

(4) Government's performance: The extent to which government keeps to the social contract by protecting and promoting the greatest good of the greatest number is yet a major determinant of political culture in Nigeria. It is worrisome that Nigeria suffers from the problem of endemic corruption and is confronted with a severe socioeconomic and political crisis of development as the country is ranked as among the most corrupt nations in the world with a score of 27 out of 100 according to the 2018 Corruption Perceptions Index (Transparency International 2018). The scenario is made more palpable due to the weak attitude of the citizenry toward participating in the government. Dike (1999) notes that there is poor attitude of the Nigerian citizenry towards effective control of the leadership and to demand transparency and accountability in governance. There are indications that endemic corruption in government have created significant levels of civic apathy in Nigeria.

(5) Gender and physical (dis)ability: Until recently, women on grounds of gender, paid less attention to political participation. For some, their spouses or parents discourage them on cultural grounds, while for some others, religious reasons are the hindrance. On the other hand, on grounds of social discrimination, the physically challenged have often been marginalized in terms of participation in politics and governance.

Considering the above determinants of opportunistic political culture in the context of the country's polity, the paper posits that the foundation of Nigerian political culture has reproduced systemic ills that negate the progress of democracy in the country. Some of the ills include political corruption, electoral malfeasance, primordial politicking, and the like (Okeke 2017).

\section{Perspectives on political culture and democratic processes}

There is no doubt that culture has been recognized as an inevitable determinant of sociopolitical development of any society. In fact, there tends to be more consensus than divergent on the relevance of culture in shaping and molding the political history, identity and destiny of any given society whether authoritarian or democratic. Polazzo (2014) observes that culture is the fulcrum around which the dynamics of a social fabric of any society revolves. The norms, values, beliefs, attitudes and traditions of the society tend to shape the political systems, institutions and processes of governance. Political culture is one of the most powerful factors that shape a political system notable for creating norms 
and beliefs that shape social behavior (Ibeanu and Orji 2014). It is a critical bedrock of any democratic political system which has the capacity to either facilitate or undermine governance in any society.

Political culture is crucial for democratic governance and stability due to its capacity to build societal perceptions and expectations necessary for political leadership. It is vitally embedded in the process of political socialization. Political culture deals with the behaviors of people in relations to political development, governance and state policies (Almond and Verba 1965; Duverger 1976). In attempt to address differences in democratic success of different countries, Laski (1986) observes that it is imperative to comprehend a country's political culture as prerequisite for understanding the design and operations of political decisions of any society.

The above indicates that political culture apart from consisting of attitude, beliefs, values and affections that are consciously held or implicit in a society in relation to its political process also has to do with people's dominant orientation towards political processes. Such orientation refers to the attitudes, beliefs and values held in relation to structures, the political authority and processes, and the way the citizens relate to the state in terms of level of participation, and efficiency of the system. The level of trust or mistrust of leadership, level of compliance, allegiance, patriotism etc., are all elements of political culture. In other words, political culture determines what is acceptable, prohibited and sanctioned in a nation's democratic processes, including electoral process.

Political culture is the manifestation of aggregate psychological and subjective dimensions of politics (Roskin 2014). Thus, it encapsulates what people believe and feel about government, and how they think people should act towards it. The manner in which people feel culminates to what they think which by extension determines what they do that accounts for their behaviors towards political processes and institutions. When and where the political values of a society are at odds with good governance and democracy, the political future becomes bleak and could revert to authoritarianism. This portends that the nature of society determines its political culture and system of organization in relations to government and political system. Political behaviors of citizens in homogeneous society are greatly similar than that of citizens in heterogeneous society. This is partly because of the uniformity and similarity in culture and beliefs in the case of homogeneous setup and disparity in same in the case of heterogeneous set up (Adibe 2014; Polazzo 2014). Essentially, political culture is embedded in the process of political socialization and thus crucial for democratic stability. In this regard, Almond and Verba (1965) note that political culture is potentially a powerful, unifying concept capable of specifying how people affect their political system, and vice-versa.

The foregoing indicates that political culture deals with the attitudes of people in relations to political development, governance processes and state policies. Duverger (1976) observes that every country has a political culture consisting of widely shared beliefs, values, and norms that define the relationship between citizens and government, 
and citizens and another. The implication is that political culture does not imply that all societies share the same set of political attitudes as the values and beliefs found in developed societies differ strikingly from those found in developing and underdeveloped societies. Adebayo and Omotola (2007) point out that political culture as a predominant beliefs, attitudes, values, ideals, sentiments, and evaluations about the political system represents a consistent pattern that influences the electoral process of any democratic society. The above assertions tend to underscore the primacy of the influence of political culture on the electoral process in any society.

Electoral process comprises of all the activities and procedures involved in the election of representatives by the electorates ranging from the provision of voter education to the dissolution of the National Assembly (Abiodun 2014; Jinadu 2007). It entails all the pre and post-election activities consisting of registration of political parties, review of voters' register, delineation of constituencies, resolution of electoral disputes, return of elected representatives and swearing-in of elected representatives. Eya (2003) posits that electoral process entails the rules that guide the conduct of election and important activities that make up an electoral process, emphasizing that any conduct that threatens the electoral process is a subversion of the peoples' sovereignty. Also, Ezeani (2005) noted that electoral process is a complex process that encompasses the good intentions and undesirable outcomes of election administration, particularly in emerging democracies where general elections are often marred by culturally hued electoral malpractices.

Electoral processes can be divided into three key phases, consisting of pre-voting, voting, and post-voting (Abiodun 2014). The pre-voting stage has to do with electoral frameworks which determine the voter eligibility. The various elements and activities of the pre-voting phase include voter and civic education, voter registration, party nominations, and electoral campaigns also take place. The voting phase involves the casting of votes, vote counting and the verification of results, announcement of result, and probable litigations. The post-voting phase has to do with the various activities that take place between different elections. These include revision of voter register, review of electoral laws amongst others.

The overall essence is to strengthen the electoral process. In this regard, Oladipupo (2011) emphasizes that the degree of transparency of electoral processes as an integral part of genuine democracy and presents a good yardstick for the determination of a country's smooth growth or retardation democratically. Sadly, conducting a free, fair and transparent election in Nigeria is a problem yet to overcome for a combination of factors; chief among which is the inherent Hobbesian nature of the state more pronounced during leadership succession process (Oladipupo 2011). The above implies that the level of openness and credibility of the electoral process and acceptability of outcomes by greatest number of the members of the society determines its capacity to guarantee political stability and political accountability which ultimately deepens democracy. 
Electoral process is therefore considered to be so crucial that some scholars have argued that it is the bedrock of all democratic regimes. Democracy is best defined in terms of electoral process, politics and the institutional parameters that underpin them (Egwu 2014). In a similar vein, Elaigwu (2014) argues that the founding pillars of any democratic political system, whether considered fragile or established, remain undoubtedly the electoral system and processes. The failure of electoral processes in Africa has been attributed to both colonial heritage as well as excesses of the political elite (Nwanegbo, Nnorom, and Odigbo 2014). It is in this regard that Nnadozie (2005) points out that the activities of different factions of the dominant political elite in the continent, prodded by their metropolitan cohorts, have made election periods contests where ethnic and other primordial sentiments are brought to the fore. Such primordial tendencies which manifest in the political culture of the citizenry tend to influence the democratic process in terms of electioneering, partisan relations, civil interest aggregation, and public policy making.

\section{Democratic opportunism and political experience in Nigeria's Fourth Republic}

The prevailing electoral process in any society has the capacity to determine how democracies could be secured and sustained (Ibeanu and Orji 2014). This suggests that it is through the electoral process that a new democracy matures, in a way that makes it unlikely to revert to authoritarianism without any backlashes. In this regard, O'Donnell (1996) postulates that democracy is consolidated when power alternates between rivals through periodic and regular elections in a manner that fosters democratic maturation. The integrity of the electoral process and its liberality is a critical determinant of democratic progress and sustenance.

Events since the return of democratic rule in Nigeria from 1999 has revealed that vote buying and vote selling have become regular occurrences before, during and after elections, thereby portending a very dangerous trend for Nigeria's democratic aspirations (Idike 2014). This holds grave implications for credible electoral process, good governance and political participation in the country. Nigeria's Fourth Republic seems to be confronted with a political culture characterized by pervasive monetization of politics, where people tend to care more for material benefits rather than the integrity of the democratic process. This is as a result of the collapse in the civic values of the people which has been accentuated by the desperate political class (Aderonke 2012). This worrisome situation is laced by ethnic, religious and regional based politics resulting to corporate national damage evident in the level of political corruption, electoral malfeasance, electioneering hooliganism, and ethnic bigotry as well as leadership rascality, national cabalism, irresponsibility and the culture of winner-takes-all. 
The political culture in the political dispensation under review is characterized by contradictions arising from political opportunism both in party politics and governance (Ayoade 2006). It is, perhaps, this precedence that prompted Genyi and Ortom (2017) to argue that elections in Nigeria are high-stakes event, whereby contestants and actors engage in sundry acts of lawlessness. Prebendalization of political power constitutes an ultimate drive for politicking. In other words, losing election means a total and irreparable loss that must be avoided by all means and at all costs. In effect, the prevailing political culture in Nigeria seems to have nurtured an abusive system where political offices bear inestimable spoils while public offices are utilized for private gains (Egharevba and Chiazor 2013; Bolaji 2014). There are pervasive manifestations of malfeasance in Nigeria's party politics (Elklit and Svensson 1997). Consequently, electoral irregularities and violence have become entrenched in the democratic process.

With reference to the April 2007 general elections, Iyayi (2007) observes that polling experience is fraught with records of high degrees of fraud, violence and criminality. Omotola (2010) observes that the 2007 elections recorded an alarming 6,180 post-election cases, owing to the high level of abuse and criminal impunity associated with the electioneering experience. The situation is made worse by some politicians who allegedly utilize the state powers to molest and neutralize perceived opponents in an attempt to win an election by all means. The inability of the security agencies to maintain professional standards during elections has been a dent in the Nigeria's electoral process. The security agents tend to serve as an instrument for an election rigging. In fact, the political experience of Nigeria since the advent of Fourth Republic has been characterized by opportunistic political culture essentialized in vote buying, thuggery, intimidation of opposition, monetization of electoral process and rampant rigging of elections (Okoli and Orinya 2013).

Vote buying has to do with the offering of any form of financial, material or promissory inducement or reward by a candidate, political party, agent or supporter to influence a voter and alter the outcome of the electoral process (Bratton 2008). Vote buying, in its literal sense, is a simple economic exchange. Here, Ojo (2006) emphasizes that candidates 'buy' and citizens 'sell' votes, as they buy and sell apples, shoes, or television sets. The act of vote buying by this view is a contract, or perhaps an auction, in which voters sell their votes to the highest bidder. In the course of Nigeria's Fourth Republic, there has been rampant act of exchanging one's own vote for material gains. When a candidate is sure of losing an election, his or her members or followers votes are traded for positions in the regime of the winners. Vote-buying at the party or flag bearer's level becomes one of the most accessible means of securing political relevance and participation. If negotiations fail to produce a workable bargain at this level, then violence takes center-stage. Knowing that losing an election in Nigeria has dire financial consequences, the certainty of candidates getting something in the end, through votebuying and other corrupt activities, encourages the willingness towards funding of 
political activities, especially elections. As such, electoral funding is an investment with (expected) returns. This scenario breeds monetization of electoral process, with its untoward consequences on the democratic process.

Monetization of electoral process arises when set financial limits, sources, and uses are either violated or abused by politicians and other relevant actors. In a situation where prescribed limits or sources of funding are ignored, the political space and the institutions governing the processes of elections and politicking become compromised. In Nigeria, legal frameworks and the implementation of the existing legal limitations regarding election financing, accounting, and auditing are weak and unsustainable (Smah 2000). The failure of the system to be transparent raises fundamental issues, which touch on justice and equity principles. The tendency to violate the laws among different political players creates a volatile system that is potentially combustible.

However, the main root of violence associated with the political processes is the zero-sum political philosophy of the political elite. Akin to this is the Hobessian tendency of some politicians that makes them see politicking as a warfare (Okoli and Orinya 2013). In addition to the zero-sum philosophy, there is an investment mentality that governs party and election funding in Nigeria. These remain the cardinal fulcrum around which the culture of violence, instantiated by assassinations, attempted assassinations or arson, is built and sustained in Nigeria's Fourth Republic. The logic of electoral politicking is such that losing an election in is tantamount to loss of political life, owing to the 'winner takes it all' syndrome. Those who win in elections do so at the expense of the losers. Hence, once an individual's chances are scuttled by opponents for whatever reason, he or she becomes completely irrelevant and estranged.

Electoral fraud, sometimes referred to as election malpractice, election manipulation or vote rigging, is illegal interference with the process of an election, either by increasing the vote share of the favored candidate, depressing the vote share of the rival candidates, or both (Kerr 2013). It connotes the subversion of the peoples' wish through the undue manipulation of the electoral process. The prevailing political culture in Nigeria is characterized by politics of desperation and brigandage, which manifests in the winner-takes-all and zero-sum politicking (Egharevba and Chiazor 2013). Odigbo (2015) points out that the repetitive patterns of electoral malpractices evident in rigging and disenfranchisement engender electoral crisis in Nigeria. Similarly, Adebayo and Omotola (2007) opine that the Nigeria's electoral politics is a veritable theatre for sundry electoral malpractices. This variously occurs in the fashion of illegal voting, electoral inducements, partisan intimidation designed to coerce actors and voters, falsification of results, and electoral thuggery (Adebayo and Omotola 2007).

It suffices to note that where the interests of the people are articulated in a free and fair election, the government in power tend to enjoy the sovereign legitimacy of the people; but election rigging can thwart the interest of the people hence the dubious imposition of an unpopular candidate. Incidentally, the ugly situation orchestrated by 
perverse political culture seems to account for the erosion of electoral integrity in Nigeria. The outcome of this anomaly has been poor leadership responsiveness, lack of accountability and legitimacy crisis.

Table1. Election-related violence and killings in Nigeria's Fourth Republic

\begin{tabular}{|c|c|c|c|}
\hline Year & State & Victims & Description of incidence \\
\hline 2007 & $\begin{array}{l}\text { Acrossthe } \\
\text { country }\end{array}$ & Over 300 & $\begin{array}{l}\text { Random killings in Northern Nigeria during } 2007 \text { post- } \\
\text { presidential election violence }\end{array}$ \\
\hline 2010 & Abia & 1 & $\begin{array}{l}\text { Comrade Chidi Nwosu suspected to have been killed by } \\
\text { unknown gunmen }\end{array}$ \\
\hline 2011 & Borno & 9 & $\begin{array}{l}\text { Engr. Fannami Gubio, Alhaji Modu-Sherrif and } 7 \text { others } \\
\text { including a ten-year old boy killed in Maiduguri near a } \\
\text { Mosque. }\end{array}$ \\
\hline 2011 & Rivers & 22 & $\begin{array}{l}\text { Pastor Julius Nwonfu, Rivers State Chairman of the All } \\
\text { Nigeria People's Party (ANPP), murdered at Port Harcourt, } \\
\text { Omagwa. Mr. Richard Nima and many people killed during } \\
\text { a political rally attended by President Goodluck Jonathan. }\end{array}$ \\
\hline 2011 & Nasarawa & 2 & $\begin{array}{l}\text { Children killed near the Palace of the Emir of Lafia in } \\
\text { Nasarawa State when police fired at anti-government } \\
\text { protesters. }\end{array}$ \\
\hline 2011 & Niger & 4 & $\begin{array}{l}4 \text { persons were killed during a political rally attended by } \\
\text { Governor Babangida Aliyu in Niger State }\end{array}$ \\
\hline 2011 & Ebonyi & 3 & $\begin{array}{l}3 \text { persons killed at Izzi LGA of Ebonyi State during a political } \\
\text { rally }\end{array}$ \\
\hline 2011 & Lagos & 3 & $\begin{array}{l}3 \text { Persons killed during a clash between the ACN and the } \\
\text { PDP supporters in Lagos. }\end{array}$ \\
\hline 2011 & Jos & 7 & $\begin{array}{l}\text { 7Persons killed during a political rally attended by Alhaji } \\
\text { Mohammed Buhari of the CPC at Jos. }\end{array}$ \\
\hline 2011 & Akwa-Ibom & 12 & $\begin{array}{l}12 \text { persons killed during a bloody clash between the ACN } \\
\text { and the PDP supporters in Akwa-Ibom. }\end{array}$ \\
\hline 2011 & Niger & 13 & $\begin{array}{l}13 \text { Persons killed through bomb blast at Suleja INEC Area } \\
\text { Office in Niger State }\end{array}$ \\
\hline 2011 & $\begin{array}{l}\text { Most Northern } \\
\text { states }\end{array}$ & Over 1,500 & $\begin{array}{l}\text { Over } 1000 \text { persons were killed in the } 2011 \text { Post- } \\
\text { presidential election violence. }\end{array}$ \\
\hline 2015 & $\begin{array}{l}\text { In } 22 \text { states of } \\
\text { the federation }\end{array}$ & 58 & 8 Nigerians killed in 2015 pre-election violence \\
\hline
\end{tabular}

Sources: Adapted from Onimishi (2015: 4), with modifications based on information from the Independent National Election Commission (INEC).

Electoral contests in Nigeria within the past two decades tend to have been characterized by massive violence that variously led to the death of politicians and candidates alike (Bratton 2008). General elections in Nigeria's Fourth Republic tend to have manifested consistent and continued pattern of political brigandage that included the killing of candidates, intimidation of voters, as well as harassment of contestants by the incumbent 
forces. Security officers and the police in particular, were widely criticized for their failure to protect voters, abuses of their human rights, failure to uphold the law and, in some cases, their direct complicity in election disruption, violence, vote rigging, intimidation and ballot box theft. Onimisi (2015) stresses that over 2,000 Nigerians have lost their lives to election related violence in the Fourth Republic. Table 1 is instructive in this respect.

Table 1 above shows, among other things, that one basic feature of electoral process in Nigeria is the over-politicization and militarization of elections that often claimed the lives and property. During and after the 2011 elections, up to 1,100 people including seven National Youth Service Corps (NYSC) members who acted as ad-hoc election workers and volunteers were killed (Onimisi 2015). Also in the 2015 elections, about 58 persons lost their lives to election-related violence. In fact, within the same period under review, Nigeria has recorded over one thousand six hundred deaths as a result of election related violence (Onimisi 2015). It is however important to state that there was a significant change during Nigeria's 2015 elections as captured by Ayanda and Odunayo (2015: 7), who opine that despite the level of competition among the two main political parties in 2015, a spirit of sportsmanship prevailed in their actions before and after the elections. None of the candidates including the incumbent was desperate for power, which resulted to minimal reported cases of rigging, manipulation of the votes, intimidation of the electorate and violence. The above scenario climaxed in the historic gesture demonstrated by the then incumbent President, Dr. Goodluck Jonathan who called and congratulated his main challenger, Muhammad Buhari, even before the final results of the elections were collated and announced.

\section{Conclusion}

This paper has established that the political culture of a country affects its democratic and governance processes. The prevailing political culture in Nigeria has been responsible for the country's democratic deficits and contradictions. Political events in Nigeria's Fourth Republic have betrayed a crisis of political culture. The dominant political orientation of Nigerians conduces to anomalies that negate progressive political development. This has negatively affected the country's democratic and governance experiences. The excesses of the political elites, exemplified in political opportunism, electoral violence, money politics, and the like, have occasioned negative tendencies that fatally threaten the prospects of consolidating both democracy and good governance in the country. This paper thus submits that the prevailing political culture in Nigeria is not amenable to both democracy and political progress of the polity. There is therefore a need for a value reorientation to develop values-sensitive and civic political culture capable of enhancing the country's democratic experience. This requires, above all, a patriotic renewal whereby particularistic cum primordial interests are transcended in deference to pro-nationalistic ideals. 


\section{References}

Abiodun, 0. 2014. "Nigerian Democracy and Electoral Process since Amalgamation: Lessons from a Turbulent Past." Journal of Humanities and Social Sciences. 19 (10): 25-37. https://doi.org/10.9790/0837-191062537

Adebayo, P. and Omotola, S. 2007. "Public perception of the 2007 Nigeria's general elections." Journal of African Elections 6 (2): 201-216. https://doi.org/10.20940/JAE/2007/v6i2a11

Aderonke, M. 2012. "Democratization and development in Nigeria: The fourth republic in Perspective." International Journal of Academic Research in Economics and Management 1 (5): 26-45.

Adibe, N. 2014. Social Media and Political Participation in West Africa: A comparative Study of the Nigeria 2011 and Ghana 2012 General Elections. Nsukka: Department of Mass Communication, University of Nigeria.

Ajayi, K. 2007. "Election Administration in Nigeria and the challenges of the 2007 elections." Medwell Journal 2 (2): 142-151.

Alabi, O.A. 2009. "Electoral Reforms and Democratic Consolidation in Nigeria: The Electoral Act 2006." CEU Political Science Journal 4 (2): 278-303.

Almond, G.A. and Verba, S. 1965. The Civic Culture: Political Attitudes and Democracy in Five Nations. Boston: Little Brown.

Ayanda, A.A. and Odunayo, B.J. 2015. "Comparative Study of 2011 and 2015 Presidential Elections in Nigeria." Global Journal of Human-Social Science: Political Science 15 (7): 48-54.

Ayoade, J. 2006. "Godfather politics in Nigeria." In: V.A.O. Adetula (eds.). IFES, money, politics and corruption in Nigeria. Abuja: IFES, 85-96.

Bratton, M. 2008. "Vote buying and violence in Nigerian elections campaigns." Electoral Studies 27 (4): 621632. https://doi.org/10.1016/j.electstud.2008.04.013

Bolaji, K.2014. "Toward Institutionalizing Credible Elections in Nigeria: A Review of Reform Measures by the Independent National Electoral Commission." In: R. Cordenillo (ed). Improving Electoral Practices: Case Studies and Practical Approaches. Stockholm: International IDEA, 50-83.

Carothers, T. 2007. "How democracies emerge: The sequencing fallacy." Journal of Democracy 18 (1): 1227. https://doi.org/10.1353/jod.2007.0002

Dahl, R. 1971. Polyarchy: Participation and Opposition. New Haven, CT: Yale University Press.

Dike, V. 1999. "The philosophy of Transforming Nigeria into a Corruption-free Society: Are the probes the Solution?" Nigeria world. 6 October 1999. [online]. [cit. 9. 4. 2020]. Available at: http://www.NigeriaWorld.com/feature/article/corruption.html

Doorenspleet, R. 2000. “Reassessing the Three Waves of Democratization.” World Politics 52 (3): 384-406. https://doi.org/10.1017/S0043887100016580

Duverger, M. 1976. The Study of Politics. London: Nelson.

Egwu, S. 2014. "Nigeria's 2015 General Election: Outlook and Challenges". West Africa Insight. [online]. [cit. 9. 4. 2020]. Available at: http://westafricainsight.org/articles/view/299

Egharevba, M.E. and Chiazor, A.I. 2013. "Political Corruption and National Development in Nigeria." International Journal of Social Sciences and Humanities Review 4 (1): 14-23. 
Elaigwu, J. 2014. “Democracy and Democratic Deficits.” In: J. Elaigwu (ed.). Federalism and Democracy in Nigeria: Fifty Years After. Jos: Institute of Governance and Social Research, 20(20).

Elklit, J. and Svensson, P. 1997. “What Makes Elections Free and Fair?” Journal of Democracy 8 (3): 32-46.

Eya, N. 2003. Electoral process, electoral malpractices and electoral violence. London: SAGE.

Ezeani, E. 2005. “Electoral Malpractices in Nigeria.” In: G. Onuh and A. Momoh (eds.). Elections and democratic consolidation in Nigeria. Lagos: A-Triad Associates, 413-431.

Genyi, G.A. and Ortom, E. 2017. "Deciding Elections in Africa: Comparative roles of the Courts and the Ballot Box in Nigeria and Kenya." Advances in Social Science Research Journal 4 (12): 141149.https://doi.org/10.14738/assrj.412.3239

Huntington, S.P. 1991. The Third Wave: Democratization in the Late Twentieth Century. Norman: University of Oklahoma Press.

Ibeanu, O. and Orji, N. 2014. Approaches to Civic and Voter Education: Nigeria's experience in comparative perspective. Lagos: Malthouse Press.

Inglehart, R. and Welzel, C. 2005. Modernization, Cultural Change and Democracy: The Human Development Sequence. Cambridge: Cambridge University Press.

Idike, A.N. 2014. "Democracy and Electoral Process in Nigeria: Problems and Prospects of E-voting Option." Asian Journal of Humanities and Social Sciences (AJHSS) 2 (2): 122-149.

Iovan, M. 2015. “The Political Culture; Political Socialization and Acculturation.” Journal of Legal Studies 16 (29): 26-47. https://doi.org/10.1515/jles-2015-0004

Iyayi, F. 2005. "Elections and electoral practices in Nigeria: Dynamics and implications." The Constitution: Journal of Constitutional Development 5 (2): 1-32.

Jackman, R. and Miller, R. 1996. “A Renaissance of Political Culture?” American Journal of Political Science 40 (3): 632-659. https://doi.org/10.2307/2111787

Jega, A. 2007. Democracy, good governance and development in Nigeria. Ibadan: Spectrum books.

Jega, A. and Ibeanu, O. (eds.) 2007. Elections and the future of democracy in Nigeria. Abuja: Nigerian Political Science Association (NPSA).

Jinadu, L. 2007. Historical Analysis of Elections and Election Management in Nigeria. Paper prepared for presentation of the Civil Society Organization meeting on electoral reform. Abuja: Open Society Initiative for West Africa (OSIWA), 19 October 2007.

Kerr, N. 2013. “Popular evaluations of elections in Africa: Evidence from Nigeria.” Electoral Studies 32 (4): 819-837. https://doi.org/10.1016/j.electstud.2013.02.010

Laski, H. 1986. A Grammar of Politics. New York: Allen and Unwin.

Linz, J. and Stepan, A. 1996. “Towards consolidated democracies.” Journal of Democracy 1 (4): 34-56. https://doi.org/10.1353/jod.1996.0031

Mbah, P. 2011. “Party Defection and Democratic Consolidation in Nigeria 1999-2009.” Afro Asian Journal of Social Sciences 2 (2): 1-21.

McFaul, M. 2002. "The Fourth Wave of Democracy and Dictatorship: Noncooperative Transitions in the Postcommunist World." World Politics 54 (2): 212-244. https://doi.org/10.1353/wp.2002.0004

Nnadozie, 0. 2005. "History of Elections in Nigeria". In: G. Onuh and A. Momoh (eds.). Elections and democratic consolidation in Nigeria. Lagos: A-Triad Associates, 112-132. 
Nwanegbo, C.J. and Alumona, I. 2011. “Incumbency factor and democratic consolidation in Nigeria's fourth republic." The Social Sciences 6 (2): 125-130. https://doi.org/10.3923/sscience.2011.125.130

Nwanegbo, C.J., Nnorom, K., and Odigbo, J. 2014. "Party defection and sustenance of Nigerian democracy." Global Journal of Human-Social Science 14 (6): 1-9.

Ojo, E.O. 2006. “Vote Buying in Nigeria." In: V.A.O. Adetula (ed.). Money, Politics and Corruption in Nigeria. Abuja: IFES, 109-122.

Odigbo J. 2015. "Instituting electoral uncertainty and untying elitist grip on Nigerian elections: An assessment of 2015 elections on democratic consolidation in Nigeria." South East Journal of Political Science 1 (1): 136-148.

O’Donnell, G. 1996. "Illusions about Consolidation." Journal of Democracy 7 (2): 34-51. https://doi.org/10.1353/jod.1996.0034

Okeke, R.C. 2017. "Political culture, democracy and development in Nigeria." Specialty Journal of Politics and Law 2 (4): 1-9.

Okeke, R.C. 2015. Harnessing Diversity of Cultural Capacities for Sustainable Development in Nigeria. Paper presented at the International Conference on Harnessing Diversity for Sustainable Development. Nsukka: Faculty of Social Sciences, University of Nsukka, 21-22 October 2015.

Okoli, A.C. and Orinya, S. 2014. "Political Opportunism and Crisis of Governance in Nigeria: Implications for sustainable statecraft and development." International Journal of Development and Sustainability 3 (7): 1477-1487.

Oladipupo, A. 2011. "Democratic Waves in West Africa: Nigeria and Ghana as case studies in view." Afro Asian Journal of Social Sciences 2 (1): 1-16.

Omotola, J.S. 2010a. "Elections and Democratic Transition in Nigeria under the Fourth Republic." African Affairs 109 (437): 535-553.https://doi.org/10.1093/afraf/adq040

Omotola, J.S. 2010b. "Political Parties and the quest for Political Stability in Nigeria." Taiwan Journal of Democracy 6 (2): 125-145.

Omotola, J.S. 2011. Management of Electoral Bodies and Democratic Consolidation in Nigeria and Ghana. Ibadan: Department of Political Science, University of Ibadan.

Omotola, J.S. 2014. "Elections and Democratic Transitions in Nigeria under the Fourth Republic." African Affairs 109 (4): 535-553. https://doi.org/10.1093/afraf/adq040

Onimishi, T. 2015. "The Prognoses of Electoral Violence in Nigeria and the Lessons for the Future." Mediterranean Journal of Social Sciences 6 (1): 242-245.

Polazzo. 2014. "Political Culture and Participation in Nigeria”. Polazzo's page. 2 October 2020. [online]. [cit. 9. 4. 2020]. Available at: www.polazzo.com/nigeria_4.htm

Przeworski, A. 1997. Democracy and the market: Political and economic reforms in Eastern Europe and Latin America. Cambridge: Cambridge University Press.

Roskin, M. 2014. Political Science and Political Culture. Encyclopedia Britannica. [online]. [cit. 9. 4. 2020]. Available at: https://www.britannica.com/topic/political-science/Historical-development

Silver, B.D. and Dowley, K.M. 2000. "Measuring political culture in multiethnic societies: Reaggregating the World Values Survey.” Comparative Political Studies 33 (4): 517-550. https://doi.org/10.1177/0010414000033004004 
Smah, S.O. undated. Money, Politics and Electoral Violence in Nigeria. Abuja: Garkida Press.

Transparency International. 2018. Corruption Perceptions Index 2018. [online]. [cit. 20. 4. 2020]. Available at: https://www.transparency.org/files/content/pages/2018_CPI_Executive_Summary.pdf

Weil, F.D. 1994. "Political Culture, Political Structure and democracy: The case of legitimation and opposition structure." In: F. Weil and M.L. Gautier (eds.). Research on Democracy and Society, Vol. 2. Political culture and political structure: Theoretical and empirical studies. Stamford: JAI Press, 65-115.

Zakaria, F. 1997. "The rise of illiberal democracy." Foreign Affairs 76 (6): 22-43. https://doi.org/10.2307/20048274 